\title{
Особливості післяопераційної реабілітації хворих на сечокам'яну хворобу
}

\begin{abstract}
Мета роботи: провести аналіз ефективності санаторно-курортної реабілітації у пацієнтів після перкутанної нефролітотрипсії. Проведено аналіз лікування 65 хворих після перкутанної нефролітотрипсії у відділенні урологічної реабілітації при Гусятинській ЦРЛ. Отримані результати порівнювали з контрольною групою (35 хворих), яким не проводилось санаторно-курортне лікування. У 64,4 \% хворих фрагменти відійшли повністю, в 25,6 \% - відійшли частково. Залишкові фрагменти не відходили зовсім або спостерігалось їх часткове відходження в пізні строки (через 1-2 місяці) - у 10 \% хворих. Отримані дані показали ефективність післяопераційної реабілітації у пацієнтів після перкутанної нефролітотрипсії порівняно з контрольною групою, яка не проходила реабілітацію на курорті Гусятин.
\end{abstract}

Ключові слова: перкутанна нефролітотрипсія; сечокам'яна хвороба; реабілітація.

Післяопераційне лікування сечокам'яної хвороби (CKX) залишається однією з найбільш актуальних і складних у сучасній урології. Поширення СКХ серед дорослого населення планети становить 1-3 \%. У структурі урологічної патології CKX займає друге місце за частотою після неспецифічних запальних захворювань і становить 3045 \% від загального числа урологічних хворих і третє - в структурі причин смертності від урологічної патології $[2,3,7]$.

Умови сучасного життя, гіподинамія, порушення кальцієвого обміну, дисбаланс $\mathrm{pH}$ сечі, пов'язаний з харчуванням, екологічні, кліматичні, географічні, а також генетичні фактори мають вирішальну роль у розвитку СКХ.

Широке розповсюдження та зростання захворюваності на СКХ зумовило пошук нових підходів до лікування цієї недугу. Останні два десятиріччя широке застосування набула перкутанна нефролітотрипсія як один з малотравматичних методів лікування СKX [5, 6, 8]. Накопичений досвід вітчизняних урологів та інших країн в цьому питанні свідчить про те, що і цей метод дає до 7-8 \% різних ускладнень [1, 4]. Після проведеного лікування методом перкутанної нефролітотрипсії повне відходження каменів протягом місяця спостерігається не більш ніж в 15 \% випадків. У решти - наявність залишкових фрагментів чи кам'яна доріжка. Крім цього, майже у всіх проявляється виражений больовий синдром (У т. ч. ниркова коліка), гематурія (макро- чи мікро-), лейкоцитурія та в окремих випадках (до 5\%) гострий пієлонефрит, що потребує госпіталізації хворих в урологічний стаціонар [2, 8].

Сприяння до самовідходження фрагментів, боротьба з інфекцією сечових шляхів, кореція $\mathrm{pH}$, профілактика рецидиву каменеутворення, нормалізація функції нирки є актуальною проблемою ведення хворих після ЕУХЛ. Ось чому реабілітація даної групи хворих має неабияке значення в практиці лікаря уролога.

Мета роботи: провести аналіз ефективності санаторно-курортної реабілітації у пацієнтів після перкутанної нефролітотрипсії.

Ми провели аналіз лікування 65 пацієнтів (дослідна група) після перкутанної нефролітотрипсії у відділенні урологічної реабілітації при Гусятинській ЦРЛ. Результати порівнювали з контрольною групою (35 пацієнтів після перкутанної нефролітотрипсії), які з тих чи інших причин не проходили комплексну реабілітацію. Слід відмітити, що постановою Кабінету Міністрів України від 28.12.1996 року "Про затвердження переліку населених пунктів, віднесених до курортних”, смт Гусятин віднесено до категорії курортних населених пунктів. Гусятин - бальнеологічний курорт з використанням слабомінералізованої води з високим вмістом органічних речовин типу “Нафтуся” під назвою “Новозбручанська” і ропи високої мінералізації типу “Друскенінкай” під назвою “Гусятинська”. Гусятинське родовище має відмінність з лікувальною водою “Нафтуся” трускавецького родовища в тому, що його складові вугільного походження.

Для оцінки стану хворих в період після перкутанної нефролітотрипсії проводилось всебічне вивчення лабораторних та клініко-рентгенологічних показників безпосередньо та у віддалені терміни після реабілітаційного лікування. Під час проведення реабілітаційного лікування постійно контролювались загальний стан хворих, наявність патологічних симптомів (які характеризували виникнення гострого запального процесу), загаль- 
ноклінічні показники (артеріальний тиск, частота пульсу та ін.), процес відходження “залишкових" фрагментів конкрементів.

Із 65 хворих дослідної групи чоловіків було 35, жінок - 30. Вік хворих знаходився в межах від 18 до 72 років. Необхідно зазначити, що показаннями до направлення пацієнтів на реабілітаційне лікування після перкутанної нефролітотрипсії були: повна фрагментація каменів на уламки, які здатні до самостійного відходження (менші 5-6 мм); відсутність гострого запального процесу у нирках; прохідність верхніх сечовивідних шляхів; відсутність супутніх захворювань в стадії загострення.

До госпіталізації у відділення реабілітації при Гусятинській ЦРЛ фрагменти після перкутанної нефролітотрипсії в мисці були виявлені у 17,6 \% пацієнтів, в чашках - у 25,9 \% хворих, у верхній третині сечоводу - у 20,4 \%, в середній - у 13,0 \% і в нижній третині сечоводу у 23,1 \%. Пацієнти були направлені у відділення реабілітації на 12-14 день після літотрипсії на термін 18-24 дні. Основним лікувальним фактором було застосування слабомінералізованої гідрокарбонатної води типу “Нафтуся". Мінеральна вода призначалася 3 відомою метою: збільшення діурезу, зменшення концентрації солей, змін $\mathrm{pH}$ сечі, полегшення відходження конкрементів, нормалізуючого впливу на запальний процес та електролітний склад сечі, покращення уродинаміки, зменшення спазму мускулатури сечовидільних шляхів i, найголовніше, зменшення літогенності сечі.

При лікуванні хворих із СКX застосування мінеральних вод проводилося строго диференційовано, з урахуванням форми захворювання, ступеня порушення функції нирок і пасажу сечі, стану серцево-судинної ситеми, маси тіла хворого, віку, інтенсивності рухового режиму і пори року.

Комплекс реабілітаційних заходів також включав дієтотерапію (відповідно до складу конкремента), ЛФК, хвойні ванни, масаж, електрофізіотерапію, гідротерапію, бальнеотерапію, теплолікування у вигляді аплікацій озокериту, циркулярний душ, електрофізіотерапевтичні заходи і медикаментозне лікування за індивідуальними показаннями.

3 перших днів від початку проведення реабілітаційних заходів спостерігали значне покращення урогемодинамічних показників функції нирок, що приводило до стимуляції скоротливих властивостей сечовивідних шляхів, збільшення діурезу, поступової нормалізації електролітного обміну в організмі, яке впливало на процес інгібіції кристалізації в сечі. Все це дозволяло досягнути прискорення відходження резидуальних фрагмен- тів роздроблених конкрементів. Після проведеного лікування був відмічений позитивний ефект у більшості пацієнтів, який полягав у відходженні фрагментів роздроблених каменів, покращенні загального самопочуття, зникненні болю та ліквідації дизуричних явищ.

Встановлено, що у 64,4 \% хворих фрагменти відійшли повністю, в 25,6 \% - відійшли частково. Залишкові фрагменти не відходили зовсім або спостерігалось їх поступове відходження в більш пізні строки (через 1-2 місяці після лікування) - у 10 \% хворих. Це можна пояснити вираженою механічною щільністю конкремента. При відходженні фрагментів помірний больовий симптом купірувався спазмолітиками. В контрольній групі (які не проходили комплексну реабілітацію) спостерігали залишкові фрагменти у 40,5 \% (за даними рентгенконтролю і УЗД), що є значно менш ефективним показником. Відсоток загострень калькульозного пієлонефриту і рецидивного каменеутворення через 1 рік після перкутанної нефролітотрипсії у хворих дослідної групи був майже в 2 рази менше, ніж у пацієнтів із контрольної групи.

Отримані результати показали, що проходження хворими після перкутанної нефролітотрипсії комплексної реабілітації з використанням слабомінералізованої води типу “Нафтуся” на курорті Гусятин є ефективніше, при порівнянні з результатами лікування аналогічних хворих, які після перкутанної нефролітотрипсії не проходили комплексної реабілітації. Потрібно зауважити, що протипоказаннями до реабілітаційного лікування хворих після перкутанної нефролітотрипсії в умовах Гусятинської ЦРЛ слід вважати: наявність фрагментів, які за своїми розмірами, формою та положенням не мають умов для просування і відходження (більше 5-6 мм), порушуючи функцію нирки та відток сечі; наявність активного запального процесу; обструктивні уропатії уродженого і набутого характеру; уролітіаз або двобічний активний запальний процес у нирках, ускладнений ХНH; камені різної локалізації, відходження яких супроводжується масивною макрогематурією; наявність супутніх захворювань, що мають загальні протипоказання до санаторно-курортного лікування.

Результати лікування хворих після перкутанної нефролітотрипсії з наступною їх реабілітацією на курорті Гусятин наглядно демонструють переваги курортної реабілітації. Слід зазначити, що тільки рання курортна реабілітація цих хворих дозволяє в короткі терміни позбавити хворого фрагментів роздроблених каменів та інших ускладнень, що виникають після перкутанної нефролітотрипсії та 


\section{ПОВІДОМЛЕННЯ}

позитивно вплинути на етіопатогенетичний фактор каменеутворення.

Висновки. 1. Комплексне лікування хворих на сечокам'яну хворобу після перкутанної нефролітотрипсії в умовах відділу реабілітації при Гусятинській ЦРЛ є одним із важливих етапів лікування цієї патології.

\section{СПИСОК ЛІТЕРАТУРИ}

1. Експерементальна рентгенкомп'ютерна денситометрія сечових конкрементів / А. О. Губарь, С. О. Возіанов, М. А. Довбиш [та ін.] // Матеріали з”їзду асоціації урологів України, 16-18 вересня, 2010 р. - С. 252-256.

2. Влияние нарушений уродинамики и сократительной функции верхних мочевыводящих путей на отхождение фрагментов камней после дистанционной литотрипсии / Н. К. Дзеранов, И. С. Мудрая, В. И. Кирпатовский [и др.] // Урология.2001. - № 2. - С. 6-9.

3. Лопаткин Н. А. Пятнадцатилетний опыт применения ДЛТ в лечении МКБ / Н. А. Лопаткин, Н. К. Дзеранов // Материалы Пленума правления Российского общества урологов. - М., 2003. - C.5-25.

4. Дистанционная ударно-волновая литотрипсия: прошлое, настоящее, будущее / Н. А. Лопаткин, М. Ф. Трапезникова, В. В. Дутов, Н. К. Дзеранов // Урология. - 2007. - № 6. -

\section{REFERENCES}

1. Hubar, A.O., Vozianov., S.O., \& Dovbysh, M.A. (2010). Eksperymentalna renthenkompiuterna densytometriia sechovykh konkrementiv [Experimental radiographic densitometry of urinary calculi]. Materialy zizdu asotsiatsii urolohiv Ukrainy - Materials of Congress of Association of Urologists of Ukraine. September, 16-18. (pp. 252-256) [in Ukrainian].

2. Dzeranov, N.K., Mudraya, I.S., \& Kirpatovskiy, V.I. (2001). Vliyaniye narusheniy urodinamiky i sokratitelnoy funktsii verkhnikh mochevyvodyashchikh putey na otkhozhdeniye fragmentov kamney posle distantsionnoy litotripsii [The influence of urodynamics and contractile function of the upper urinary tract on the discharge of stone fragments after distance lithotripsy]. Urologiya - Urology, 2, 6-9 [in Russian].

3. Lopatkin, N.A., \& Dzeranov, N.K. (2003). Pyatnitsaletniy opyt primeneniya DLT v lechenii MKB [Fifteen years of experience with DLT in the treatment of KSD]. Materialy Plenuma pravleniya Rossiyskogo obshchestva urologov - Materials of the Plenum of the Board of the Russian Society of Urology, 5-25 [in Russian]. 4. Lopatkin, N.A., Trapeznikova, M.F., Dutov, V.V., \& Dze-
2. Використання в комплексному лікуванні природних властивостей слабомінералізованої води за типом “Нафтуся” сприяє компенсації порушених функцій нирок і організму в цілому, профілактиці рецидивного каменеутворення, більш швидкій елімінації фрагментів роздроблених каменів та поверненню пацієнтів до повноцінної трудової діяльності.

C. 3-13.

5. Пасечников С. П. Современные аспекты цитратной терапии при мочекаменной болезни. Опыт применения препарата Уралит-У/ С. П. Пасечников, М. В. Митченко // Здоровье мужчины. -2007. - № 3. - С. 109-113.

6. Optimal treatment for distal ureteral calculi: Extracorporeal shockwave lithotripsy versus ureteroscopy / C.-P. Chang, S.-H. Huang, H.-L. Tai [et al.] // Journal of Endourology. - 2001. - Vol. 15, No. 6. - P. 563-566.

7. Extracorporal shockwave lithotripsy in patients with distal ureteral calculi does not influence the prostate spesific antigen value / C. H. Deliveliotis, J. Varkarakis, E. Alagrof, A. Skolarikos // Journal of Andrology. - Vol. 15, No. 10.

8. Ureteric stents increase the number of shock wave adsession of ESWL to clear of ureeric stones / H. Milad, L. Mark, E. Uwechue [et al.] // European Urology. - 2002. - (Suppl. 1), No. 1. - P. 38.

ranov, N.K. (2007). Distantsionnaya udarno-volnovaya litotripsiya: proshloye, nastoyashchee, budushchee [Remote shock wave lithotripsy: Past, present, future]. Urologiya - Urology, 6, 3-13 [in Russian].

5. Pasechnikov, S.P., \& Mitchenko, M.V. (2007). Sovremennye aspekty tsitratnoy terapii pri mochekamyanoy bolezni. Opyt primeneniya preparata Uralit-U [Current aspects of citrate therapy for urolithiasis. The experience of using the drug Uralit-U]. Zdorovye muzhchiny - Health of a Man, 3, 109-113 [in Russian]. 6. Chang, C.-P., Huang, S.-H., \& Tai, H.-L. (2001). Optimal treatment for distal ureteral calculi: Extracorporeal shockwave lithotripsy versus ureteroscopy. Journal of Endourology, 15 (6), 563-566.

7. Deliveliotis, C.H., Varkarakis, J., Alagrof, E., \& Skolarikos, A. Extracorporal shockwave lithotripsy in patients with distal ureteral calculi does not influence the prostate spesific antigen value. Journal of Andrology, 15 (10).

8. Milad, H., Mark, L., \& Uwechue, E. (2002). Ureteric stents increase the number of shock wave adsession of ESWL to clear of ureeric stones. European Urology (1), 1, 38.

Отримано 06.10.2019 
V. V. TVERDOKHLIB, A. I. MYSAK, S. O. NESTERUK, T. T. STAKHIV

I. Horbachevsky Ternopil National Medical University

\title{
FEATURES OF POSTOPERATIVE REHABILITATION OF PATIENTS WITH UROLITHSASIS
}

The aim of the work: to analyze the effectiveness of sanatorium-resort rehabilitation in patients after percutaneous nephrolithotripsy. An analysis was made of the treatment of 65 patients after percutaneous nephrolithotripsy in the Urological Rehabilitation Department at Husiatyn District Hospital. The obtained results were compared with a control group (35 patients) who had not undergone sanatorium-resort treatment. In $64.4 \%$ of patients the fragments went out completely, in $25.6 \%$ - partially departed. The residual fragments did not go away completely, or there was a partial withdrawal in late terms (after 1-2 months) - in $10 \%$ of patients. The data obtained showed the effectiveness of postoperative rehabilitation in patients after percutaneous nephrolithotripsy compared with the control group that did not undergo rehabilitation at the resort of Husiatyn.

Key words: percutaneous nephrolithotripsy; urolithiasis; rehabilitation.

\author{
В. В. ТВЕРДОХЛИБ, А. И. МЫСАК, С. А. НЕСТЕРУК, Т. Т. СТАХИВ
}

Тернопольский национальный медицинский университет имени И. Я. Горбачевского МОз Украины

\section{ОСОБЕННОСТИ ПОС.ЕОПЕРАЦИОННОЙ РЕАБИЛИТАЦИИ БОЛЬНЫХ МОЧЕКАМЕННОЙ БО.ЛЕЗНЬЮ}

Цель работы: провести анализ эффективности санаторно-курортной реабилитации у пациентов после перкутанной нефролитотрипсии.

Проведен анализ лечения 65 больных после перкутанной нефролитотрипсии в отделении урологической реабилитации при Гусятинской ЦРБ. Полученные результаты сравнивали с контрольной группой (35 больных), которым не проводилось санаторно-курортное лечение. В 64,4 \% больных фрагменты отошли полностью, в 25,6 \% - отошли частично. Остаточные фрагменты не отходили совсем или наблюдалось их частичное отхождение в поздние сроки (через 1-2 месяца) - у 10 \% больных. Полученные данные показали эффективность послеоперационной реабилитации у пациентов после перкутанной нефролитотрипсии по сравнению с контрольной группой, которая не проходила реабилитацию на курорте Гусятин.

Ключевые слова: перкутанная нефролитотрипсия; мочекаменная болезнь; реабилитация. 